\title{
WDR45 mutations may cause a MECP2 mutation-negative Rett syndrome phenotype
}

\author{
Leonora Kulikovskaja, MS, Adrijan Sarajlija, MD, Dusanka Savic-Pavicevic, PhD, Valerija Dobricic, PhD, \\ Christine Klein, MD, and Ana Westenberger, PhD
}

Neurol Genet 2018;4:e227. doi:10.1212/NXG.0000000000000227

\author{
Correspondence \\ Dr. Klein \\ christine.klein@ \\ neuro.uni-luebeck.de
}

Mutations in the autophagy-related WD domain repeat 45 (WDR45) gene cause beta-propeller protein-associated neurodegeneration (BPAN), a distinct form of neurodegeneration with brain iron accumulation (NBIA). ${ }^{1,2}$ Clinical and imaging features comprise childhood-onset global developmental delay with further regression in early adulthood, progressive dystonia, parkinsonism, stereotypies, and iron deposition in the basal ganglia. Female and the few existing male patients show similar phenotypes, probably because of somatic mosaicism in males and skewed X-chromosome inactivation (XCI) in females, as WDR45 is located on $\mathrm{Xp} 11.23$. To date, about 60 cases have been reported, many of whom had a different initial clinical diagnosis. ${ }^{3}$ Hyperkinetic movements and stereotypies overlap with Rett syndrome features, another $\mathrm{X}$-linked disorder most commonly caused by MECP2 mutations. Indeed, for $7 \%$ of the reported cases of BPAN, the initial diagnosis was Rett syndrome, ${ }^{3}$ prompting us to perform the first mutational screen of the WDR45 gene in a large cohort of MECP2 mutation-negative Rett syndrome patients.

\section{Methods}

We sequenced exons 3-12 covering the coding region of WDR45 (ENST00000356463, NM_0007075) in 40 patients with Rett(-like) syndrome from Serbia, including 2 male patients. All patients had been tested negative for mutations in the $M E C P 2$ gene. In identified sequence change carriers, the XCI pattern was studied using the human androgen receptor assay (HUMARA) as described in reference 4. X-inactivation ratios of less than or equal to 80:20 were considered to represent a random pattern, and ratios greater than 80:20 were considered to indicate a skewed pattern. ${ }^{4}$ MutationTaster (mutationtaster.org/) and CADD (cadd.gs. washington.edu/score) were used for in-silico prediction analysis. The study was approved by the local ethics committee.

\section{Results}

Sanger sequencing of WDR45 revealed 1 novel, likely pathogenic (c.319_320delCT) and 1 benign (c.20G>A) change in 2 female patients (figure A). Patient A carrying the novel deletion presented with classic Rett syndrome and was 6 years old at the last follow-up. Her early motor development was normal, and she started to sit independently at the age of 7 months and walk at the age of 14 months. She showed no speech development, and microcephaly was noted. At the age of 24 months, she developed bruxism and stereotypic movements, followed by epileptic seizures at the age of 36 months. Family history is negative. The c.319_320delCT deletion (figure $\mathrm{A}$ ) is situated in exon 6 and is predicted to cause a frameshift and introduce a premature stop codon ( $\mathrm{p}$. Leu107Phefs*7) likely leading to nonsense-mediated mRNA decay. 
A

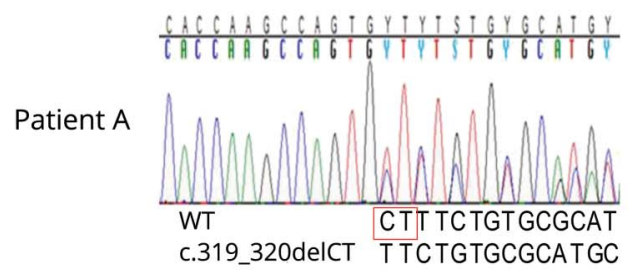

B

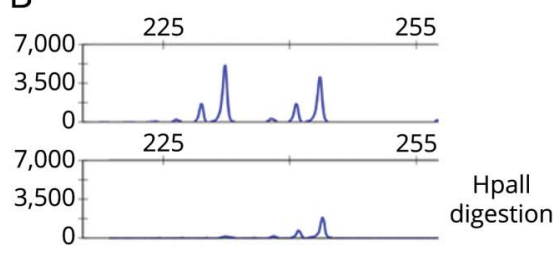

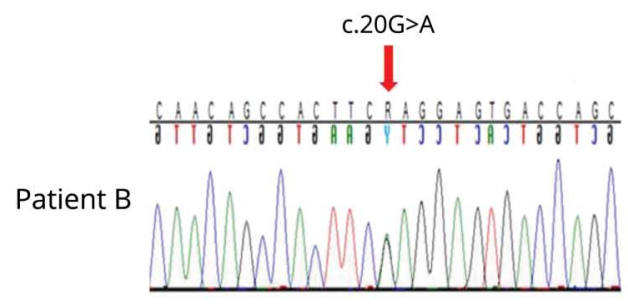

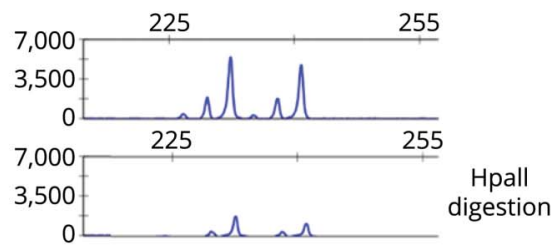

(A) Sanger sequence electropherograms of genomic PCR amplicons of patients A (exon 6, c.319_320delCT, p.L107Ffs*7) and B (exon 3, c.20G>A, p.Arg7GIn). The 2 deleted nucleotides are boxed in red. The arrow above the lower electropherogram marks the exact position of the missense mutation. (B) X-chromosome inactivation $(\mathrm{XCl})$ patterns show skewed $\mathrm{XCl}$ for patient $\mathrm{A}(89: 11)$ and random $\mathrm{XCl}$ $(56: 44)$ for patient $B$.

MutationTaster designated this change as disease causing, and the CADD score for this mutation is 28.5 . No entry was found in the publicly available databases 1000G (ncbi.nlm.nih.gov/ variation/tools/1000genomes/) or ExAC. ${ }^{5}$ The HUMARA assay indicated skewed XCI (89:11) (figure B).

No detailed information was available for the carrier of the missense change (patient B) who was lost to follow-up but also presented with typical clinical features of Rett syndrome. Although the c.20G >A (p.Arg7Gln) (figure A) change is also predicted to be disease causing by MutationTaster and CADD (score of 25.4), it was listed in ExAC, with an allele count of $3 / 86,473$. $^{5}$ It is important that 2 of the 3 alleles were found in the hemizygous state in male individuals (in 30/30 and 40/43 reads, excluding the possibility of mosaicism). ${ }^{5}$ No entry was found in 1000G. XCI was found to be random (56:44) (figure B).

\section{Discussion}

Considering the phenotypic overlap between Rett syndrome and BPAN and the fact that $8 \%$ of seemingly typical and $42 \%$ of atypical Rett syndrome patients screen negative for MECP2 mutations, ${ }^{6}$ we screened a cohort of 40 Serbian patients with Rett(-like) syndrome and found 2 changes in WDR45. The deletion c.319_320delCT in patient $A$ is likely causative for BPAN, whereas the missense change c.20G $>A$ in patient $B$ is unlikely to be pathogenic. Although the change occurs in a highly conserved region, the 3 alleles found in the ExAC database harboring this mutation, including 2 hemizygous ones, render it an unlikely genetic cause of BPAN. Furthermore, individuals affected with severe pediatric disease are not part of the ExAC data set. ${ }^{5}$ Unfortunately, brain magnetic resonance imaging (MRI) scans of both patients were unavailable and could thus not be reviewed for evidence of brain iron accumulation.

In agreement with previously published observations, ${ }^{3}$ our finding emphasizes the need for the WDR45 gene to be included in panel analyses not only for neurodegeneration with brain iron accumulation but also for patients with Rett (-like) syndrome. Furthermore, the growing evidence for a predominant skewed XCI pattern in BPAN and other $\mathrm{X}$-linked disorders raises the question of the underlying mechanisms regulating XCI, which are still incompletely understood. $1,2,7$

\section{Author contributions}

Leonora Kulikovskaja: study concept and design, acquisition, analysis, and interpretation of data, and writing of the first draft. Adrijan Sarajlija: acquisition of data and critical revision of the manuscript for important intellectual content. Dusanka Savic-Pavicevic, Valerija Dobricic, and Christine Klein: study supervision and critical revision of the manuscript for important intellectual content. Ana Westenberger: study concept and design, analysis and interpretation of data, and critical revision of the manuscript for important intellectual content.

\section{Study funding}

The project was funded by the Hermann and Lilly Schilling Foundation (to Christine Klein). The authors acknowledge financial support by Land Schleswig-Holstein within the funding programme Open Access Publikationsfonds for the open access publication process.

\section{Disclosure}

Leonora Kulikovskaja, Adrijan Sarajlija, Dusanka SavicPavicevic, and Valerija Dobricic report no disclosures. 
Christine Klein is an associate editor of Annals of Neurology. She serves as a medical advisor of Centogene and Biogen. She is the recipient of a career development award from the Hermann and Lilly Schilling Foundation. She is funded by the Deutsche Forschungsgemeinschaft, the European Union, and the Possehl Foundation and received institutional support from the University of Lübeck for genetics research. Ana Westenberger is funded by the Deutsche Forschungsgemeinschaft. Full disclosure form information provided by the authors is available with the full text of this article at Neurology.org/NG.

Received December 7, 2017. Accepted in final form February 8, 2018.

\section{References}

1. Haack TB, Hogarth P, Kruer MC, et al. Exome sequencing reveals de novo WDR45 mutations causing a phenotypically distinct, X-linked dominant form of NBIA. Am J Hum Genet 2012;91:1144-1149.

2. Saitsu H, Nishimura T, Muramatsu K, et al. De novo mutations in the autophagy gene WDR45 cause static encephalopathy of childhood with neurodegeneration in adulthood. Nat Genet 2013;45:445-449;449.e1.

3. Hoffjan S, Ibisler A, Tschentscher A, Dekomien G, Bidinost C, Rosa AL. WDR45 mutations in Rett (-like) syndrome and developmental delay: case report and an appraisal of the literature. Mol Cell Probes 2016;30:44-49.

4. Allen RC, Zoghbi HY, Moseley AB, Rosenblatt HM, Belmont JW. Methylation of HpaII and HhaI sites near the polymorphic CAG repeat in the human androgen-receptor gene correlates with X chromosome inactivation. Am J Hum Genet 1992;51:1229-1239.

5. Lek M, Karczewski KJ, Minikel EV, et al. Analysis of protein-coding genetic variation in 60,706 humans. Nature 2016;536:285.

6. Percy AK. Rett syndrome: recent research progress. J Child Neurol 2008;23:543-549.

7. Zarate YA, Jones JR, Jones MA, et al. Lessons from a pair of siblings with BPAN. Eur J Hum Genet 2016;24:1095. 


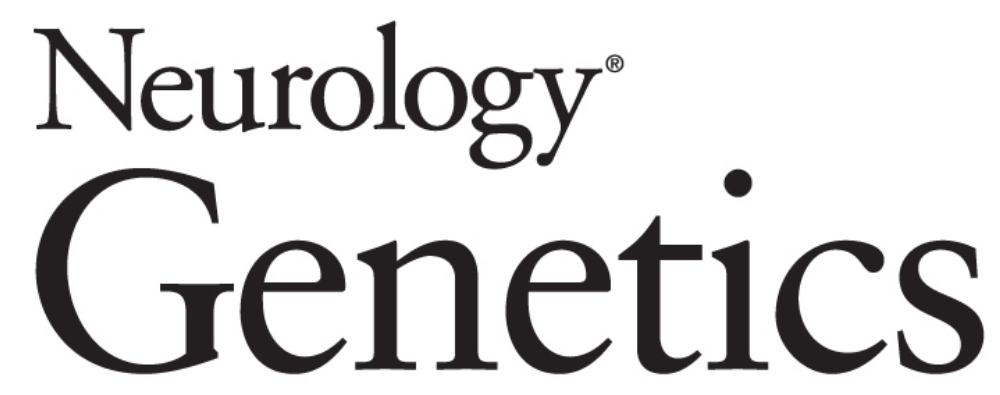

WDR45 mutations may cause a MECP2 mutation-negative Rett syndrome phenotype Leonora Kulikovskaja, Adrijan Sarajlija, Dusanka Savic-Pavicevic, et al. Neurol Genet 2018;4;

DOI 10.1212/NXG.0000000000000227

This information is current as of March 27, 2018

\section{Updated Information \&} Services

References

Subspecialty Collections

Permissions \& Licensing

Reprints including high resolution figures, can be found at: http://ng.neurology.org/content/4/2/e227.full.html

This article cites 7 articles, 0 of which you can access for free at: http://ng.neurology.org/content/4/2/e227.full.html\#\#ref-list-1

This article, along with others on similar topics, appears in the following collection(s):

All Genetics

http://ng.neurology.org//cgi/collection/all_genetics

Rett Syndrome

http://ng.neurology.org//cgi/collection/rett_syndrome

Information about reproducing this article in parts (figures,tables) or in its entirety can be found online at:

http://ng.neurology.org/misc/about.xhtml\#permissions

Information about ordering reprints can be found online: http://ng.neurology.org/misc/addir.xhtml\#reprintsus

Neurol Genet is an official journal of the American Academy of Neurology. Published since April 2015, it is an open-access, online-only, continuous publication journal. Copyright Copyright ( 2018 The Author(s). Published by Wolters Kluwer Health, Inc. on behalf of the American Academy of Neurology.. All rights reserved. Online ISSN: 2376-7839.

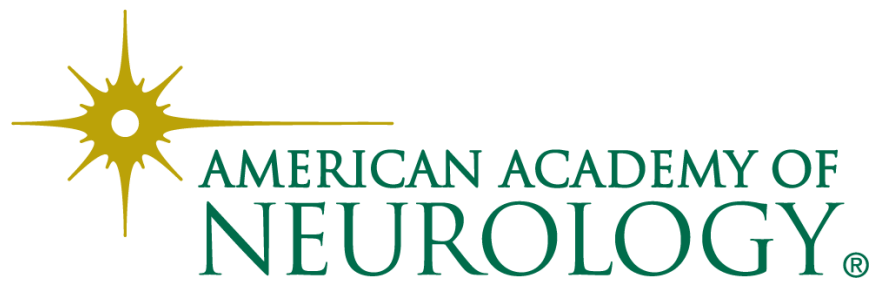

